\title{
UPAYA PENINGKATAN KONSEP DIRI POSITIF PESERTA DIDIK KELAS XII SMA NAHDLATUL ULAMA 1 GRESIK MELALUI FORGIVENESS THERAPY
}

\author{
Muhammad Badril Riza \\ SMA Nahdlatul Ulama 1 Gresik, Jawa Timur, Indonesia \\ badrilrizanol@gmail.com
}

\begin{abstract}
Background - There are indications of low positive self-concept, especially in class XII students. Often the negative self-concept experienced by students is more influenced by unfinished emotion, namely feelings of being wronged in the past by the surrounding environment that has not been resolved so as to form various consequences of unconscious behavior in the present

Objective - Describe the application of classical forgiveness therapy guidance services in improving the positive self-concept of class XII students of SMA Nahdlatul Ulama 1 Gresik.

Design / methodology / approach - action research guidance and counseling (PTBK).

Findings - Improvements in classical guidance services from cycle 1 to cycle 2 have succeeded in increasing the positive self-concept of students as evidenced by the decline in students in the low and very low categories on the results of the self-concept questionnaire.

Research implications - This study provides contributions in the management of students' self-concepts. Research limitations - This research on guidance and counseling was carried out with due regard to pandemic conditions during the study. So that service settings are also limited by space (keep distance) and time. For further researchers, this can be done more optimally through different service designs under normal conditions.
\end{abstract}

Keywords: Self-Concept, Forgiveness Therapy, PTBK

\begin{abstract}
Abstrak
Latar Belakang - Adanya indikasi rendahnya konsep diri positif, khususnya pada peserta didik kelas XII. Seringkali konsep diri negatif yang dialami oleh peserta didik lebih dipengaruhi oleh unfinished emotion, yakni perasaan terdzalimi pada masa lalu oleh lingkungan sekitar yang belum terselesaikan sehingga membentuk berbagai akibat perilaku tidak sadar dimasa kini Tujuan - Mendiskripsikan penerapan layanan bimbingan klasikal forgiveness therapy dalam meningkatkan konsep diri positif peserta didik kelas XII SMA Nahdlatul Ulama 1 Gresik.

Desain / metodologi / pendekatan - penelitian tindakan bimbingan dan konseling (PTBK).

Temuan - Perbaikan layanan bimbingan klasikal dari siklus 1 menuju siklus 2 telah berhasil meningkatkan konsep diri positif peserta didik dibuktikan dengan semakin menurunnya peserta didik pada kategori rendah dan sangat rendah pada hasil angket konsep diri.

Implikasi penelitian - Penelitian ini berkontribusi dalam manajemen konsep diri peserta didik. Batasan penelitian - Penelitian tindakan bimbingan dan konseling ini dilakukan dengan memperhatikan kondisi pandemi saat penelitian berlangsung. Sehingga setting layanan juga terbatas oleh ruang (jaga jarak) dan waktu. Bagi peneliti selanjutnya bisa dilakukan dengan lebih maksimal melalui desain layanan yang berbeda pada kondisi normal.
\end{abstract}

Kata kunci : Konsep Diri, Forgiveness Therapy, PTBK 


\section{PENDAHULUAN}

Sekolah Menengah Atas (SMA) merupakan salah satu jenjang pendidikan formal dimana peserta didiknya merupakan anak usia remaja yakni pada usia sekitar 15 th s/d 18th. Pada masa remaja sering disebut sebagai masa pencarian jati diri dengan adanya berbagai tuntutan atas dasar perkembangan dan pertumbuhan fisik serta psikis. Remaja berusia 12-25 tahun merasakan masa krisis yang penuh gejolak akibat pertentangan nilai karena perubahan perkembangan secara fisik, intelektual dan emosional. Santrock (2005) menjelaskan bahwa masa remaja berakhir pada sekitar usia 18 hingga 22 tahun. Periode ini masa paling kritis bagi remaja dalam mencari jati dirinya.

Pembentukan konsep diri pada remaja sangat penting karena akan mempengaruhi kepribadian, tingkah laku dan pemahaman terhadap diri sendiri. Konsep diri merupakan gambaran individu tentang dirinya yang individu ketahui tentang dirinya, bagaimana individu memandang dan menilai dirinya. Konsep diri yang dimiliki seorang individu tidak langsung terbentuk ketika ia lahir di dunia, melainkan konsep diri itu terbentuk dan berkembang sepanjang rentang kehidupannya. Idrus (2019) menjelaskan bahwa konsep diri bisa dipengaruhi beberapa aspek, yakni pengalaman masa lalu dan opini publik.

Pengalaman masa lalu yang yang diserap oleh seseorang sebagai pengalaman secara emosional akan mempengaurhi believe pada dirinya yang kemudian menentukan bagaimana dia bersikap, Misalnya saja saya pernah melakukan konseling dengan peserta didik yang sangat sering ceroboh dalam bertindak dan seolah selalu melakukan kesalahan-kesalahan kecil yang harusnya tidak perlu terjadi, setelah beberapa kali sesi konseling terungkap bahwa sejak kecil dia sering disalahkan oleh orang tuanya ketika melakukan berbagai hal, hingga suatu saat orang tuanya marah dan berucap "kamu itu mengerjakan apa saja kok selalu salah, tidak pernah betul!". Hal tersebut ternyata diinterpretasikan oleh pikirannya sebagai pengalaman penuh emosional dan menjadikan dirinya kurang percaya diri dan kurang terampil melakukan berbagai hal.

Konsep diri juga tidak bisa lepas dari lingkungan (opini publik), anak yang tumbuh dilingkungan penuh rasa empati, cinta, motivasi dan rutinitas yang positif akan terdorong untuk melakukan hal yang sama dan lebih mudah menumbuhkan rasa percaya diri serta bakat minatnya. Sebaliknya anak yang tumbuh dilingkungan yang 
apatis, penuh rasa curiga, tidak percaya, saling menyalahkan, dan rutinitas yang negatif maka akan sulit baginya mennumbuhkan rasa percaya diri.

Secara empiris, peneliti menemukan adanya indikasi rendahnya konsep diri positif, khususnya pada peserta didik kelas XII. Beberapa kondisi yang nampak sebagai indikasi rendahnya konsep diri positif adalah adanya permasalahan ketidak percayaan diri, termasuk ketidakmampuan peserta didik untuk menghargai kemampuan pribadinya dan mengakui keberhargaan dirinya. Hal tersebut didapatkan dari data konseling 1 tahun terakhir, dari 16 layanan konseling yang dilakukan oleh peneliti 12 diantaranya berhubungan dengan rendahnya konsep diri negatif. Juga dari hasil angket konsep diri yang diberikan peneliti sebagai pre-test yang didapatkan hasil 7 orang $(29,1 \%)$ pada kategori konsep diri rendah dan 2 orang $(8,3 \%)$ pada kategori sangat rendah.

Peneliti juga menemukan pola bahwa seringkali konsep diri negatif yang dialami oleh peserta didik lebih dipengaruhi oleh unfinished emotion, yakni perasaan terdzalimi pada masa lalu oleh lingkungan sekitar yang belum terselesaikan sehingga membentuk berbagai akibat perilaku tidak sadar dimasa kini seperti contoh yang peneliti ungkapkan diatas, atau contoh lainnya dimana peneliti melakukan terapi pada peserta didik baru yang tidak percaya diri ketika berada pada kerumunan teman kelasnya, bahkan ia mengalami psikosomatis dengan merasa mual dan pusing. Setelah dua kali sesi konseling ditemukan sebab bahwa ia mengalami pengalaman tidak menyenangkan ketika kelas 1 SMP, dimana dia dihukum oleh seorang guru untuk berkeliling sekolah dengan mengenakan tulisan "saya datang terlambat" yang digantungkan di lehernya. Sontak saja, teman yang melihatnya menertawakan dan hal tersebut ternyata membekas hingga dia SMA, pengalaman itu terinternalisasi dalam ingatannya dan perasaan dipermalukannya muncul dalam diri namun dia tidak berdaya untuk mengungkapkan.

Dalam upaya membantu hal tersebut sebetulnya guru BK telah memberikan layanan bimbingan klasikal mengenai pentingnya membentuk konsep diri positif, namun hal tersebut tidak berdampak signifikan karena layanan yang diberikan hanya sebatas memenuhi tujuan khusus kognitif peserta didik tentang bagaimana meningkatkan konsep diri positif. Berangkat dari evaluasi proses dan hasil layanan bimbingan klasikal sebelumnya maka peneliti melakukan penelitian tindakan bimbingan dan konseling (PTBK) dengan menggunakan forgiveness therapy (terapi pemaafan) sebagai layanan klasikal yang akan diberikan. 


\section{TINJAUAN PUSTAKA}

Konsep diri individu bukanlah bawaan dari lahir namun terbentuk dengan adanya pengalaman, persepsi serta hasil belajar yang dialami oleh setiap individu. Konsep diri seseorang terbentuk dari proses belajar. Sesuai dengan yang diungkapkan Watson (Ahmadi, 2009) "Manusia waktu lahir masih bersih maka untuk menjadikan manusia sesuai dengan yang dikendaki, diberikan pengalaman-pengalaman dan lingkungan".

Selain itu, Desmita (2011) juga menyebutkan bahwa “Konsep diri terbentuk melalui proses belajar sejak masa pertumbuhan berlangsung hingga dewasa, selain itu pola asuh orang tua juga mempengaruhi pembentukan konsep diri setiap individu". Selanjutnya M. Argyhe (dalam Hardy dan Heyes 1988) menyebutkan terdapat "Empat faktor yang berkaitan dengan konsep diri: reaksi diri yang dilakukan orang lain, peranan seseorang, perbandingan dengan orang lain, dan identifikasi terhadap orang lain". Lis, dkk (2012) menyatakan bahwa "Konsep diri dapat terbentuk dan berkembang melalui pengalaman dan pandangan dari lingkungan sekitar, penilaian orang lain, dan perilaku diri sendiri." Dari berbagai sumber diatas dapat disimpulkan bahwa banyak faktor yang membentuk konsep diri remaja, salah satunya adalah pengalaman-pengalaman individu terhadap kejadian dilingkungan mereka baik yang terjadi di masa lalu maupun di masa kini.

Menurut Thomson dkk (2005) memaafkan berhubungan terhadap cara pandang masa lalu oleh individu. Pemaafan merupakan persepsi mengenai pelaku, respon terhadap pelaku yang semulanya negatif berubah menjadi netral atau positif. McCullogh (2000) memandang pemaafan adalah serangkaian perubahan motivasi untuk menurunkan penghindaran terhadap pelaku, hasrat untuk membalas dendam dan meningkatkan motivasi untuk berbuat kebaikan terhadap pelaku. Serangkaian motivasi ini diharapkan dapat memberikan energi pada perubahan perilaku yang berdampak pada rekonsiliasi hubungan antara korban dan pelaku.

Berdasarkan pendapat dari beberapa ahli dapat disimpulkan pemaafan merupakan serangkaian perubahan motivasi dan emosi negatif mengenai pelaku menjadi emosi netral atau positif. Perubahan emosi dan motivasi diukur berdasarkan penurunannya motivasi menghindari pelaku, balas dendam serta meningkatnya motivasi untuk berbuat baik terhadap pelaku.

Penelitian terdahulu juga mendukung bahwa terapi pemaafan mampu meningkatkan konsep diri positif. Penelitian oleh Oktandhy dkk (2019) dengan judul 
"Pengaruh Terapi Pemaafan untuk Meningkatkan Penerimaan Diri pada Orang dengan HIV/AIDS" menunjukkan hasil ada perubahan signifikan dalam penerimaan diri oleh subjek penelitian setelah mendapatkan terapi pemaafan.

Harapannya setelah mendapatkan layanan bimbingan klasikal forgiveness therapy, peserta didik mampu meningkatkan konsep diri positifnya sebagai individu yang lebih baik dan bahagia. Perlu diketahui bahwa jumlah maksimal penulis naskah penelitian adalah 3 orang.

\section{METODOLOGI PENELITIAN}

Metode penelitian yang digunakan dalam penelitian ini ialah penelitian tindakan bimbingan dan konseling (PTBK). PTBK dalam pengertian ini diorientasikan pada PTK. Menurut Wardhani dkk, (2007), penelitian tindakan kelas merupakan penelitian yang dilakukan oleh guru didalam kelasnya sendiri melalui refleksi diri, dengan tujuan untuk memperbaiki kinerjanya sebagai guru, sehingga hasil belajar siswa menjadi meningkat.

Dalam penelitian tindakan kelas ini desain penelitian tindakan kelas yang digunakan adalah desain PTK Model Kemmis \& Mc Taggart. Dalam perencanaanya, Kemmis menggunakan sistem spiral refleksi diri yang dimulai dengan Rencana; Tindakan, Pengamatan, dan Refleksi dan perencanaan kembali (Kusumah dan Dwitagama, 2010). Penelitian tindakan kelas ini dilakukan dalam bentuk siklus, siklus yang dirancang dalam penelitian ini sebanyak 2 siklus. Masing-masing siklus memiliki 4 tahapan yaitu: melakukan perencanaan, menentukan tindakan, melakukan pengamatan (observasi), serta melakukan refleksi pada hasil. Setelah siklus 1 dilakukan selanjutnya mempersiapkan perencanaan ulang untuk siklus 2 yang didasarkan pada hasil pengamatan pada siklus 1 .

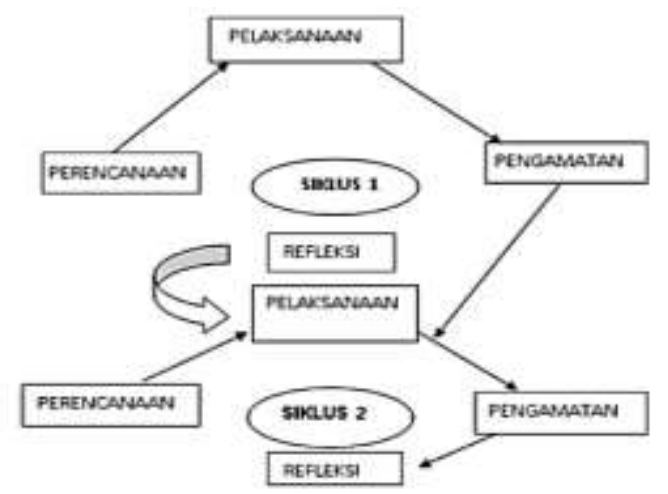

Gambar 1

Bagan siklus penelitian tindakan bimbingan dan konseling (PTBK) 
Berikut detail tahapan pelaksanaan pada siklus 1 dan siklus 2 :

Kegiatan Inti layanan bimbingan klasikal forgiveness therapy siklus 1 :

1. Guru BK menayangkan materi power point singkat mengenai konsep diri dan tehnik meningkatkan konsep diri positif melalui forgiveness therapy (Fase pembukaan/ Uncovering Phase).

2. Guru BK melakukan proses brainstorming kondisi konsep diri peserta didik. (Fase pengambilan keputusan/ Decision Phase)

a. Guru BK menunjuk beberapa peserta didik untuk menyampaikan pendapatnya mengenai konsep dirinya

b. Guru BK memberikan pertanyaan kepada peserta didik secara acak mengenai pengalaman pribadi meningkatkan konsep diri positif

c. Guru BK memberikan trigger kepada peserta didik tentang pentingnya pengaruh forgiveness therapy dalam peningkatan konsep diri positif

3. Guru BK membuka sesi Tanya jawab mengenai konsep diri.

4. Guru BK memberikan link Audio Forgiveness Therapy kepada peserta didik untuk didengarkan secara mandiri. (Fase Tindakan/Action Phase)

5. Guru BK memberikan link LKPD kepada peserta didik.

Kegiatan inti layanan bimbingan klasikal forgiveness therapy siklus 2 :

1. Guru BK menayangkan materi power point singkat mengenai konsep diri dan tehnik meningkatkan konsep diri positif melalui forgiveness therapy dengan tehnik diagram kehidupan

2. Guru BK mengulas kembali materi layanan siklus 1 sebagai penguatan pentingnya forgiveness therapy (Decision Phase).

3. Guru BK melaksanakan sesi diagram kehidupan

a. Guru BK membagi peserta didik menjadi 3 kelompok kecil

b. Guru BK menjelaskan regulasi pelaksanaan teknik diagram kehidupan

c. Setiap anak mendapatkan 1 kertas millimeter

d. Kelompok kecil membuat formasi duduk melingkar dengan lilin aromaterapi ditengah lingkaran

e. Setiap peserta didik membuat diagram kehidupan sesuai dengan kondisi dirinya (Uncovering Phase) 
f. Setiap peserta didik menceritakan diagram kehidupannya dalam kelompok kecil (Action phase)

g. Setiap anggota wajib mendengarkan dan membangun sikap simpati serta empati.

4. Guru BK melakukan sesi relaksasi virtual forgiveness therapy (Action Phase)

Subjek dalam penelitian ini adalah siswa kelas XII MIPA 5 sebanyak 24 orang. Subjek dipilih berdasarkan hasil analisa data konseling yang memiliki topik konseling konsep diri negatif paling banyak dari kelas yang ditangani oleh peneliti.

Teknik analisis data yang digunakan adalah untuk menganalisis pada bagian :

1. Skor tingkat konsep diri peserta didik

Skor tingkat konsep diri peserta didik diperoleh dari hasil angket konsep diri yang diberikan 3 kali, yakni sebelum layanan, setelah layanan siklus 1, dan setelah layanan siklus 2. Angket konsep diri mengadopsi dari penelitian sebelumnya yang telah melalui uji validitas dan realibilitas.

Analisis data angket menggunakan analisis deskriptif. Analisis deskriptif dalam penelitian ini meliputi skor rata-rata (mean), skor paling sering muncul (modus), skor tengah (median), simpangan baku (std. deviation), skor maksimum (max), skor minimum (min), rentang (range), yang selanjutnya disajikan dalam bentuk tabel.

Data yang telah dianalisis diklasifikasikan menurut kecenderungan data. Pengkategorian berdasarkan nilai mean skor keseluruhan $(\mathrm{X})$ dan simpangan baku skor keseluruhan (SBx). Nilai-nilai tersebut dapat dikategorikan dalam empat klasifikasi seperti terlihat pada tabel berikut :

Tabel 1

Kategorisasi/Interpretasi hasil pengukuran angket konsep diri

\begin{tabular}{|l|l|l|}
\hline No & Rentang Skor & Kategori \\
\hline 1 & $X \geq X+1$. SB $x$ & Sangat Tinggi \\
\hline 2 & $x+1$. SB $x>X \geq X$ & Tinggi \\
\hline 3 & $x>X \geq x-1$. SB $x$ & Rendah \\
\hline 4 & $X<x-1$. SB $x$ & Sangat Rendah \\
\hline
\end{tabular}

(Sumber: Djemari Mardapi, 2008)

Keterangan :

$\mathrm{X} \quad=$ Skor yang dicapai

$X \quad=$ Rerata $/$ mean skor keseluruhan

$=1 / 2$ (skor tertinggi + skor terendah)

$\mathrm{SBx}=$ Simpangan baku skor keseluruhan $=1 / 6$ (skor tertinggi - skor terendah) 


\section{Lembar Observasi}

Lembar observasi ini adalah lembar pengamatan yang diisi oleh observer (koordinator guru BK dan Wali Kelas). Hasil data observasi diolah dan dianalisis setelah penelitian tindakan diberikan, hasil data diolah sesegera mungkin agar dapat menjadi rujukan bagi siklus berikutnya. Hasil observasi yang diterima dari hasil pengamatan observer kemudian dianalisis dan didiskusikan mengenai hal-hal yang perlu diperbaiki pada siklus berikutnya.

Penilaian lembar observasi menggunakan 4 jenjang skor yakni Sangat Baik (SB) 4 skor, Baik (B) 3 skor, Kurang (K) 2 skor, Sangat Kurang (SK) 1 skor dengan total skor maksimal 60 skor. Lembar observasi dinalisis menggunakan rumus

$N A=\frac{\text { jumlah skor yang diperoleh siswa }}{\text { jumlah skor maksimal (60) }} \times 100 \%$

Hasil tersebut kemudian diklasifikasikan dengan tabel kriteria dibawah ini :

Tabel 2

Kriteria Penilaian Lembar Observasi

\begin{tabular}{|c|c|}
\hline Skor $(\%)$ & Deskripsi \\
\hline $0-25$ & Sangat Kurang \\
\hline $26-50$ & Kurang \\
\hline $51-75$ & Baik \\
\hline $75-100$ & Sangat Baik \\
\hline
\end{tabular}

\section{HASIL DAN PEMBAHASAN}

Bab ini akan menyajikan hasil penelitian dan pembahasan, yakni mendiskripsikan penerapan layanan bimbingan klasikal forgiveness therapy dalam meningkatkan konsep diri positif peserta didik kelas XII SMA Nahdlatul Ulama 1 Gresik. Dari hasil pengelolaan data angket konsep diri peserta didik dapat dideskripsikan terjadi peningkatan konsep diri positif peserta didik. Berikut disajikan data hasil angket konsep diri dari tahap pre-test, post-test siklus 1, dan post-test siklus 2.

\section{Tahap pra siklus}

Pada tahap pra siklus, peserta didik mendapatkan angket konsep diri yang harus diisi sesuai dengan kondisi dirinya, angket ini nantinya juga sebagai acuan awal kondisi konsep diri peserta didik. Berikut hasil angket konsep diri pada pra siklus : 
Tabel 3

Statistik konsep diri pre-test

\begin{tabular}{|c|c|}
\hline STATISTIK & JUMLAH \\
\hline Jumlah Responden $(\mathrm{N})$ & 24 \\
\hline Skor maksimum (max) & 86 \\
\hline Skor minimum (min) & 53 \\
\hline Simpangan Baku (std. deviation) & 4 \\
\hline Skor rerata (mean) & 69 \\
\hline
\end{tabular}

Tabel 4

Kategorisasi hasil instrument angket konsep diri pre-test

\begin{tabular}{|c|c|c|c|}
\hline KATEGORI & INTERVAL & JUMLAH & PROSENTASE \\
\hline Sangat Tinggi & $X \geq 75$ & 11 & $45,8 \%$ \\
\hline Tinggi & $75>X \geq 69$ & 4 & $16,7 \%$ \\
\hline Rendah & $69>X \geq 65$ & 7 & $29,1 \%$ \\
\hline Sangat Rendah & $X<65$ & 2 & $8,3 \%$ \\
\hline
\end{tabular}

Dari tabel diatas dapat dideskripsikan bahwa pada hasil pre-test didapatkan sebanyak 7 orang peserta didik $(29,1 \%)$ memiliki konsep diri rendah, dan sebanyak 2 orang peserta didik $(8,3 \%)$ memiliki konsep diri sangat rendah. Sehingga diperlukan tindakan pada siklus 1 PTBK.

\section{Tahap siklus 1}

Pada siklus 1, peserta didik mendapatkan layanan bimbingan klasikal secara daring/online. Aplikasi yang diguanakan adalah zoom meeting, adapun hasil angket konsep diri pada siklus 1 PTBK sebagai berikut :

Tabel 5

Statistik konsep diri post-test siklus 1

\begin{tabular}{|c|c|}
\hline STATISTIK & JUMLAH \\
\hline Jumlah Responden (N) & 24 \\
\hline Skor maksimum (max) & 86 \\
\hline Skor minimum (min) & 53 \\
\hline Simpangan Baku (std. deviation) & 4 \\
\hline Skor rerata (mean) & 69 \\
\hline
\end{tabular}

Tabel 6

Kategorisasi hasil instrument angket konsep diri post-test siklus I

\begin{tabular}{|c|c|c|c|}
\hline KATEGORI & INTERVAL & JUMLAH & PROSENTASE \\
\hline Sangat Tinggi & $X \geq 75$ & 14 & $58,3 \%$ \\
\hline Tinggi & $75>X \geq 69$ & 5 & $20,8 \%$ \\
\hline Rendah & $69>X \geq 65$ & 4 & $26,7 \%$ \\
\hline Sangat Rendah & $X<65$ & 1 & $4,2 \%$ \\
\hline
\end{tabular}


Pada hasil angket konsep diri siklus I terdapat 4 orang peserta didik (16,7\%) berada pada kategori rendah dan 1 orang peserta didik $(4,1 \%)$ berada pada kategori sangat rendah. Sedangkan pada kategori sangat tinggi terdapat 14 orang peserta didik $(58,3 \%)$, dan pada kategori tinggi terdapat 5 orang peserta didik $(20,8 \%)$.

\section{Tahap siklus 2}

Pada siklus 2, layanan dilakukan secara tatap muka langsung. Pemberian layanan bimbingan kelompok forgiveness therapy dibagi menjadi 2 sesi dengan membagi 24 subjek menjadi 2. Hal ini agar layanan berjalan secara maksimal. Berikut hasil angket konsep diri pada tahap siklus 2 PTBK :

Tabel 7

Statistik konsep diri siklus 2

\begin{tabular}{|c|c|}
\hline STATISTIK & JUMLAH \\
\hline Jumlah Responden (N) & 24 \\
\hline Skor maksimum (max) & 86 \\
\hline Skor minimum (min) & 61 \\
\hline Simpangan Baku (std. deviation) & 4,2 \\
\hline Skor rerata (mean) & 77,7 \\
\hline
\end{tabular}

Tabel 8

Kategorisasi hasil instrument angket konsep diri siklus 2

\begin{tabular}{|c|c|c|c|}
\hline KATEGORI & INTERVAL & JUMLAH & PROSENTASE \\
\hline Sangat Tinggi & $X \geq 77,7$ & 7 & $58,3 \%$ \\
\hline Tinggi & $77,7>X \geq 73,5$ & 15 & $20,8 \%$ \\
\hline Rendah & $73,5>X \geq 69,3$ & 1 & $26,7 \%$ \\
\hline Sangat Rendah & $X<69,3$ & 1 & $4,2 \%$ \\
\hline
\end{tabular}

Pada hasil angket konsep diri siklus I terdapat 4 orang peserta didik (16,7\%) berada pada kategori rendah dan 1 orang peserta didik $(4,1 \%)$ berada pada kategori sangat rendah. Sedangkan pada hasil angket konsep diri siklus II hanya terdapat 1 orang peserta didik $(4,1 \%)$ berada pada kategori sangat rendah dengan skor total 69 dan 1 orang peserta didik $(4,1 \%)$ berada pada kategori rendah dengan skor total 72 .

Berdasar hasil analisa yang diuraikan sebelumnya, menunjukkan adanya peningkatan konsep diri positif peserta didik setelah mengikuti layanan bimbingan klasikal forgiveness therapy sebanyak 2 siklus. Dengan demikian hipotesis penelitian yang berbunyi "ada peningkatan konsep diri positif peserta didik setelah mendapatkan layanan forgiveness therapy" dapat diterima. 


\section{KESIMPULAN}

Berdasarkan hasil penelitian tindakan bimbingan dan konseling terhadap siswa kelas XII MIPA 5 SMA Nahdlatul Ulama 1 Gresik yang telah dideskripsikan pada uraian sebelumnya maka diperoleh kesimpulan sebagai berikut :

1. Penerapan forgiveness therapy dalam layanan bimbingan klasikal dapat membantu meningkatkan konsep diri positif peserta didik

2. Pada pra siklus dapat dideskripsikan bahwa sebanyak 7 orang peserta didik $(29,1 \%)$ memiliki konsep diri rendah, dan sebanyak 2 orang peserta didik $(8,3 \%)$ memiliki konsep diri sangat rendah.

3. Pada layanan siklus 1 terdapat 4 orang peserta didik $(16,7 \%)$ berada pada kategori rendah dan 1 orang peserta didik $(4,1 \%)$ berada pada kategori sangat rendah. Sedangkan pada kategori sangat tinggi terdapat 14 orang peserta didik $(58,3 \%)$, dan pada kategori tinggi terdapat 5 orang peserta didik (20,8\%).

4. Pada layanan siklus 2, dilakukan layanan bimbingan klasikal dengan strategi tatap muka langsung dengan waktu 2×45 menit. Hasil konsep diri siklus 2 hanya terdapat 1 orang peserta didik $(4,1 \%)$ berada pada kategori sangat rendah dengan skor total 69 dan 1 orang peserta didik $(4,1 \%)$ berada pada kategori rendah dengan skor total 72. Dipastikan terjadi peningkatan konsep diri positif dari siklus 1 ke siklus 2 .

5. Dari hasil observasi oleh observer serta evaluasi proses dan hasil didapatkan bahwa perbaikan layanan bimbingan klasikal dari siklus 1 menuju siklus 2 telah berhasil meningkatkan konsep diri positif peserta didik dibuktikan dengan semakin menurunnya peserta didik pada kategori rendah dan sangat rendah pada hasil angket konsep diri.

\section{REKOMENDASI}

Berdasarkan hasil temuan yang ada di lapangan selama pelaksanaan penelitian, maka saran yang bisa diberikan pada beberapa pihak adalah sebagai berikut :

1. Bagi Konselor

Desain layanan bimbingan klasikal dengan topik forgiveness therapy yang telah dijalankan harapannya bisa diberikan kepada setiap kelas sebagai bentuk rencana tindak lanjut, dimana dalam pelaksanaannya juga terus dilakukan perbaikan perbaikan agar layanan semakin maksimal. Juga sebagai pengimbasan best practice maka perlu dilakukan kolaborasi dengan guru BK yang lain dalam pelaksanaannya. 
2. Bagi peneliti selanjutnya

Penelitian tindakan bimbingan dan konseling ini dilakukan dengan memperhatikan kondisi pandemi saat penelitian berlangsung. Sehingga setting layanan juga terbatas oleh ruang (jaga jarak) dan waktu. Bagi peneliti selanjutnya bisa dilakukan dengan lebih maksimal melalui desain layanan yang berbeda pada kondisi normal.

\section{DAFTAR PUSTAKA}

A. Thompson., Arthur Jr., dkk., (2005). Crafting and executing strategy. United States: McGraw-Hill.

Ahmadi, Abu. (2009). Psikologi Umum. Jakarta: Rineka Cipta.

Desmita. (2011). Psikologi Perkembangan Peserta Didik. Bandung: Rosda Karya.

Hardy, M dan Hayes,S. (1988). Pengantar Psikologi. Jakarta : PT Erlangga.

Idrus. (2019). Modul Personality Mastery. Surabaya : Idrusputra

Kusumah, Wijaya dan Dedi Dwitagama. (2010). Mengenal Penelitian Tindakan Kelas. Jakarta: PT INDEKS

Lis, dkk. (2012). "Kematangan Emosi, Konsep Diri, dan Kenakalan Remaja". Jurnal Persona, Vol. 1 No.1. dari http://jurnal.untagsby.ac.id/ index.php/persona/article/viewFile/9/25 (diakses 1 November 2020)

McCullough, Michael E. (2000). Forgiveness as Human Strength : Theory, Measurement, and Links to Well-Being. Journal of Social and Clinical Psychology. 19, 43-55

Oktandhy Bhayatri Mochammad Firmansyah, Khoiruddin Bashori, Elli Nur Hayati. (2019). Pengaruh Terapi Pemaafan Dengan Dzikir Untuk Meningkatkan Penerimaan Diri Pada Orang Dengan Hiv/ Aids (Odha).

Santrock, J.W. (2005). Adolescence, Perkembangan Remaja. Jakarta: Erlangga.

Wardhani, Igak. Dkk. 2007. Penelitian Tindakan Kelas. Jakarta: Universitas Terbuka 